\title{
Pengaruh Stres Terhadap Pertumbuhan Janin dan Kadar Kortisol Plasma Serum Tikus (Rattus norvegicus) Bunting yang Terpapar Stressor Renjatan Listrik
}

\author{
Zilfi Yola Pitri ${ }^{1}$, Hirowati Ali $^{2}$, Desmiwarti ${ }^{3}$
}

\begin{abstract}
Abstrak
Kondisi stres pada saat kehamilan akan berpengaruh terhadap perubahan hormon dan pertumbuhan janin, terutama pada hormon kortisol dan akan mengakibatkan pertumbuhan janin terganggu seperti berat badan lahir rendah dan panjang badan yang tidak normal. Tujuan: Menentukan pengaruh stres terhadap pertumbuhan janin dan kadar kortisol. Metode: Ini adalah penelitian eskperimental dengan desain post test only terhadap 32 ekor tikus bunting yang terbagi atas kelompok kontrol dan kelompok perlakuan. Pemeriksaan kadar kortisol menggunakan metode Enzym-Linked Immunosorbent Assay (ELISA) dengan mengalirkan arus listrik $25 \mathrm{~V}$, frekuensi $60 \mathrm{~Hz}$ selama 14 hari di laboratorium Biomedik Fakultas Kedokteran Universitas Andalas dari Februari sampai Maret 2019 dengan teknik total sampling menggunakan independent t-test. Hasil: Analisis statistik menunjukkan bahwa terdapat pengaruh yang signifikan pada berat badan $(p=0,000)$, panjang badan $(p=0,000)$ dan kadar kortisol $(p=0,024)$ terhadap stres. Simpulan: stres dapat meningkatkan kadar kortisol dan mempengaruhi pertumbuhan janin seperti berat badan dan panjang badan janin.
\end{abstract}

Kata kunci: stres kehamilan, pertumbuhan janin, kadar kortisol

\section{Abstract}

Stressful conditions during pregnancy will affect hormonal changes and fetal growth, especially on the hormone cortisol and will result in impaired fetal growth such as low birth weight and abnormal body length. Objectives: to determined the effect of stress on fetal growth and cortisol levels. Methods:This study was an experimental study with post test only design on thirty two pregnant rats divided into control group and the treatment group. Cortisol level was measured by Enzymed Linked Immunosorbent Assay (ELISA) method by flowing $25 \mathrm{~V}$ electric current, frequency 60 $\mathrm{Hz}$ for 14 days in the Biomedical Laboratory of the Medical Faculty of Andalas University from February until March 2019 with total sampling technique using the independent $t$-test. Results: Statistical analysis showed that there was a significant effect on body weight $(p=0,000)$, body length $(p=0,000)$ and cortisol levels $(p=0,024)$ on stress. Conclusions: Stress can increase cortisol levels and affect fetal growth such as body weight and fetal body length.

Keywords: stress in pregnancy, fetal growth, hormone cortisol

Affiliasi penulis: 1. Prodi Magister Kebidanan Fakultas Kedokteran Universitas Andalas Padang (FK Unand), 2. Bagian Biokimia FK Unand, 3. Bagian Obstetri Ginekologi FK Unand

Korespondensi: dr. Hirowati Ali,PhD Email :

hirowati_ali@yahoo.com Telp: 082288295160

\section{PENDAHULUAN}

Stres adalah pengalaman emosional negatif yang timbul dengan menunjukan perubahan yang terjadi baik secara biokimia, fisiologis, kognitif dan perilaku yang akan memberikan dampak pada tubuh seseorang. Orang yang mengalami stres akan berdampak pada kondisi mental emosional yang tidak menyenangkan dan tidak stabil. ${ }^{1}$

Berdasarkan data dari Badan Kesehatan Dunia (WHO) memperkirakan sekitar 450 juta orang dewasa di seluruh dunia mengalami stres, dan diantaranya sekitar $10 \%$ telah mengalami gangguan jiwa dan sekitar $25 \%$ pada usia $18-21$ tahun akan mengalami 
gangguan jiwa, pada tahun 2030 diperkirakan akan meningkat secara terus menerus sekitar $26,2 \%$, hal ini disebabkan dari berbagai faktor pencetus yang dapat mengganggu emosi dan kejiwaan seseorang. ${ }^{2}$

Prevalensi stres nasional tahun 2013 adalah sebesar $60 \%$ atau secara absolut lebih dari 10 juta jiwa. Prevalensi gangguan mental dan emosional tertinggi terdapat di Provinsi Sumatera Barat sebesar $11,6 \%$ sedangkan yang terendah di provinsi Lampung $1,2 \%$ dari penduduk provinsi tersebut. ${ }^{3}$

Pertumbuhan janin terganggu mengakibatkan gangguan pada berat badan lahir dan panjang badan yang tidak normal, dibuktikan dari data yaitu sekitar $75,3 \%$ mengalami hipotermia, 69,8\% mengalami malnutrisi, 54,3\% mengalami gangguan pertumbuhan dan $45,78 \%$ terjadi gangguan imun. ${ }^{4}$

Seorang wanita yang sedang hamil akan rentan terhadap penyakit dan komplikasi, hal ini disebabkan karena keadaan emosional yang tidak stabil dan psikologis yang terganggu, keadaan demikian disebabkan karena adanya perubahan hormon yang terjadi di dalam tubuh perempuan hamil, namun setiap ibu hamil mempunyai respon yang berbeda-beda menanggapi respon stres yang dialaminya, hal ini terjadi karena pada saat tubuh bertemu dengan stressor, tubuh akan mengaktifkan sistem saraf dan hormon untuk melaksanakan pertahanan untuk mengatasi tindakan darurat. ${ }^{5}$

Gejala stres dapat menyebabkan peningkatan produksi adrenalin dan menyebabkan kondisi wapada (state of alarm), akan tetapi hal ini dapat diatasi, tetapi apabila stres terus berlanjut maka akan terjadi resistensi melalui mekanisme coping secara mental yang dapat menyebabkan gangguan mental dan fisik. ${ }^{6}$

Stres dapat merangsang hipotalamus untuk menghasilkan Corticotropic Releasing Hormone $(\mathrm{CRH})$ yang akan menyebabkan pelepasan Adreno Cortiicotropin Hormone (ACTH) di hipofisis. Pelepasan ACTH akan menimbulkan rangsangan pada korteks adrenal yang pada akhirnya akan melepaskan hormon kortisol. Dalam keadaan normal, kortisol dilepaskan dalam jumlah yang sangat kecil sepanjang hari, namun dalam keadaan stres kadar hormon kortisol akan meningkat secara drastis bahkan dapat meningkat 20 kali. Kadar kortisol yang tinggi tidak dapat menginhibisi sekresi $\mathrm{CRH}$ dan $\mathrm{ACTH}$ dikarenakan reseptor glukokortikoid menurun pada saat mengalami stres. ${ }^{5}$

Penelitian yang dilakukan oleh Sugito et al (2012) pada tikus putih (Rattus Norvegicus) bahwa pembentukan kortisol dan sekresi kortisol meningkat enam kali pada seekor tikus dalam waktu 4 sampai 20 menit setelah dilakukan fraktur pada kedua tulang kakinya yang menyebabkan tikus tersebut stres, ${ }^{7} \mathrm{Hal}$ ini sejalan dengan kepustakaan bahwa stres dapat menyebabkan peningkatan sekresi ACTH oleh kelenjer hipofisis anterior yang diikuti dengan peningkatan sekresi hormon berupa kortisol dalam waktu beberapa menit. $^{8}$

Berdasarkan pemaparan diatas, diketahui stres memiliki pengaruh cukup besar terhadap pertumbuhan janin, oleh karena itu peneliti tertarik melakukan penelitian untuk mengetahui pengaruh stres terhadap pertumbuhan janin dan kadar kortisol plasma serum tikus (Rattus norvegicus) bunting yang terpapar stressor renjatan listrik di Laboratorium Farmakologi Fakultas Farmasi Universitas Andalas Padang.

\section{METODE}

Penelitian ini merupakan studi eksperimental dengan desain post test only control group di Laboratorium Farmakologi Fakultas Farmasi Universitas Andalas Padang untuk mengetahui pengaruh stres terhadap pertumbuhan janin dan kadar kortisol plasma serum tikus (Rattus norvegicus) bunting yang terpapar stressor renjatan listrik.

Penelitian dilaksanakan pada Februari sampai Maret 2019. Populasi dari penelitian ini adalah tikus (Rattus norvegicus) bunting yang di dapat di unit pemeliharaan hewan percobaan Laboratorium Farmakologi Fakultas Farmasi Universitas Andalas Padang. Subjek penelitian yang dipilih adalah yang memenuhi kriteria inklusi dan eklusi. Dimana kriteria inklusinya yaitu tikus betina, umur tikus 10 minggu, berat tikus 250-300 gram, tikus dalam keadaan sehat, tidak ada kelainan anatomis. Sedangkan kriteria ekslusinya yaitu tikus sakit dan tikus mati. Besar sampel dalam penelitian ini adalah kelompok kontrol $(n=16)$ dan kelompok perlakuan $(n=16)$.

Pemeriksaan kadar kortisol dengan menggunakan metode Enzym-Linked Immunosorbent Assay (ELISA). Berat badan janin yang telah diberikan 
stressor renjatan listrik dinilai dengan menggunakan timbangan digital Kern dan Sohn dengan tingkat ketelitian 0,01 gram kemudian panjang badan janin diukur menggunakan jangka sorong dengan tingkat ketelitian 0,01 cm, teknik pengukuran dari ujung kepala (vertex) sampai ujung ruas tulang belakang atau bokong. Data dianalisis menggunakan uji tIndependent dan uji Mann-Whitney, hasil dikatakan terdapat perbedaan yang bermakna jika $p<0,05$.

\section{HASIL}

Hasil yang didapatkan dari penelitian terhadap masing-masing kelompok terdiri dari 16 kelompok kontrol (tidak stres) dan 16 kelompok perlakuan (diberikan stres) dengan jumlah sampel sebanyak 32 ekor tikus. Adapun hasilnya di tampilkan dalam tabel berikut.

Tabel 1. Uji normalitas pengaruh stres terhadap berat badan, panjang badan dan kadar kortisol tikus (Rattus norvegicus) bunting

\begin{tabular}{cccc}
\hline Variabel & Kelompok & $\mathbf{n}$ & $\mathbf{p}$ \\
\hline Berat Badan $(\mathrm{gr})$ & Stres & 16 & 0,946 \\
& Tidak Stres & 16 & 0,112 \\
\hline $\begin{array}{c}\text { Panjang Badan } \\
(\mathrm{cm})\end{array}$ & Stres & 16 & 0,166 \\
\hline $\begin{array}{c}\text { Kadar Kortisol } \\
(\mathrm{ng} / \mathrm{ml})\end{array}$ & Tidak Stres & 16 & 0,756 \\
\hline & Stres & 16 & 0,638 \\
& Tidak Stres & 16 & 0,072 \\
\hline
\end{tabular}

Tabel 1 menunjukan bahwa hasil uji normalitas berat badan, panjang badan, kortisol diperoleh nilai $p \geq 0,05$ yang berarti bahwa data terdistribusi normal, maka dilanjutkan dengan uji parametrik yaitu independent $t$-test.

Tabel 2. Pengaruh stres terhadap berat badan janin tikus (Rattus norvegicus) bunting pada induk yang mngalami stres $(+)$ dengan yang tidak mengalami stres (-)

\begin{tabular}{lccc}
\hline Kelompok & \multicolumn{3}{c}{ Berat Badan } \\
\cline { 2 - 4 } & Rerata (gr) & SD & $\mathbf{p}$ \\
\hline Stres (+) & 3,50 & 0,07 & \\
Tidak Stres (-) & 4,71 & 0,09 & 0,000 \\
\hline
\end{tabular}

Tabel 2 menunjukkan rerata berat badan janin pada induk yang mengalami stres $(+)$ adalah $(3,50 \pm$ $0,07)$ gram. Berat badan janin pada induk yang tidak mengalami stres (-) adalah 4,71 $\pm 0,09$ ) gram. Hasil uji t-independent berpasangan dengan nilai $p=0,000$ $(p \leq 0,05)$, sehingga dapat disimpulkan bahwa terdapat perbedaan yang signifikan antara berat badan janin pada induk yang mengalami stres (+) dengan yang tidak mengalami stres (-).

Tabel 3. Pengaruh stres terhadap panjang badan lahir janin tikus (Rattus norvegicus) bunting pada induk yang mengalami stres (+) dengan yang tidak mengalami stres (-)

\begin{tabular}{lccc}
\hline Kelompok & \multicolumn{3}{c}{ Panjang Badan } \\
\cline { 2 - 4 } & Rerata (cm) & SD & p \\
\hline Stres (+) & 2,39 & 0,11 & \\
Tidak Stres (-) & 3,30 & 0,04 & 0,000 \\
\hline
\end{tabular}

Tabel 3 menunjukkan rerata panjang badan janin pada induk yang mengalami stres (+) adalah $(2,39 \pm 0,11) \mathrm{cm}$. Panjang badan janin pada induk yang tidak mengalami stres (-) adalah $(3,30 \pm 0,04)$ $\mathrm{cm}$. Hasil uji $t$-independent berpasangan dengan nilai $p=0,000(p \leq 0,05)$, sehingga dapat disimpulkan bahwa terdapat perbedaan yang signifikan antara panjang badan janin pada induk yang mengalami stres (+) dengan yang tidak mengalami stres (-).

Tabel 4. Pengaruh stres terhadap kadar kortisol pada induk yang mengalami stres (+) dengan yang tidak mengalami stres (-)

\begin{tabular}{lcrc}
\hline Kelompok & \multicolumn{3}{c}{ Kortisol } \\
\cline { 2 - 4 } & $\begin{array}{r}\text { Rerata } \\
(\mathbf{n g} / \mathbf{m l})\end{array}$ & SD & p \\
& 62,42 & 8,59 & \\
\hline Stres (+) & 55,12 & 8,75 & 0,024 \\
\hline
\end{tabular}

Tabel 4 menunjukkan rerata kadar kortisol pada induk yang mengalami stres $(+)$ adalah $(62,42 \pm$ 8,59) $\mathrm{ng} / \mathrm{ml}$. Kadar kortisol pada induk yang tidak mengalami stres (-) adalah $(55,12 \pm 8,75) \mathrm{ng} / \mathrm{ml}$. Hasil uji $t$-independent berpasangan dengan nilai $p=0,024$ $(p \leq 0,05)$, sehingga dapat disimpulkan bahwa terdapat 
perbedaan yang signifikan antara kadar kortisol pada induk yang mengalami stres (+) dengan yang tidak mengalami stres (-).

\section{PEMBAHASAN}

Pada penelitian ini didapatkan hasil yaitu terdapat perbedaan yang bermakna pengaruh stres pada berat badan janin, panjang badan janin dan kadar kortisol serum pada induk yang terpapar stressor renjatan listrik (+) dengan yang tidak diberikan stressor renjatan listrik (-) dengan $p>0,05$.

Berdasarkan hasil pengukuran berat badan janin pada induk yang mengalami stres (+) sebesar $(3,50 \mathrm{gr} \pm 0,07)$, lebih ringan dibandingkan berat badan janin pada induk yang tidak mengalami stres (-) sebesar $(4,71 \mathrm{gr} \pm 0,09)$. Hasil yang sama juga diperlihatkan pada panjang badan janin pada induk yang mengalami stres $(+)$ sebesar $(2,39 \mathrm{~cm} \pm 0,1)$, lebih kecil dibandingkan pada induk yang tidak mengalami stres (-) sebesar $(3,30 \mathrm{~cm} \pm 0,04)$.

Menurut Pudjonarko et al (2008), bahwa kontak langsung dengan arus listrik (electrical foot shock) sebesar 25 A pada tikus wistar dapat menyebabkan stres dan nyeri, hal ini disebabkan besar nilai arus arus listrik tersebut merupakan ambang terjadinya paralisis otot yang kontak langsung dengan sumber listrik. Arus listrik tersebut akan berkontak dengan serabut aferen tidak bermielin yang mana nantinya serabut ini akan memproduksi substansi $\mathrm{P}$ di daerah ekstraseluler. Substansi $P$ ini dapat mengaktivasi serabut tidak bermielin untuk melepaskan histamin dari sel mast sehingga menyebabkan nyeri. Pada saat pemberian perlakuan pada tikus hamil dengan memberikan renjatan listrik melalui sengatan listrik pada kaki tikus, menimbulkan reaksi pergerakan dengan melompat dan bersuara cicitan bahkan ada yang mengeluarkan feses. Ini menandakan tikus tersebut mngalami nyeri pada saat perlakuan diberikan. Stres fisik merupakan stresor eksternal yang disebabkan oleh kondisi dari luar tubuh yang memberikan respon pada tubuh. Pemberian renjatan listrik pada tikus perlakuan secara berkelanjutan dengan durasi yang meningkat setiap harinya selama 14 hari kehamilan sehingga menyebabkan tikus tidak dapat untuk beradaptasi ${ }^{9}$
Stres yang terjadi secara berulang dan terus menerus mengakibatkan hipotalamus mensekresikan Corticotropin Releasing Hormone $(\mathrm{CRH})$ yang akan menginduksi hipofisis antrior untuk mensekresi ACTH. ACTH yang adekuat dapat merangsang adrenal untuk mensekresikan hormon kortisol, epinefrin dan norepinefrin dalam tanggapan tubuh untuk menekan stres yang diterimanya. ${ }^{10}$

Respon penolakan tubuh ibu dengan cara peningkatan kadar kortisol dalam darah untuk meningkatkan proses katabolisme energi dapat secara langsung mempengaruhi plasenta dan janin. Pada keadaan lanjut, hormon kortisol akan meningkatkan katabolisme dalam tubuh ibu hamil yang nantinya akan berujung pada penurunan nutrisi ibu yang akan diterima janin. ${ }^{9}$

Adanya peningkatan kadar kortisol tubuh maka akan mempengaruhi semua aktivitas fisiologi tubuh sampai ke tingkat biomolekuler yang menyebabkan pertumbuhan janin menjadi terganggu seperti berat badan lahir rendah dan panjang badan yang tidak normal, hal ini disebabkan oleh peningkatan kadar kortisol sebagai respon terhadap peningkatan kadar progesteron pada kehamilan yang diperlukan untuk keadaan homeostasis, dengan adanya peningkatan hormon kortisol dapat mempengaruhi seluruh metabolisme tubuh. Hal inilah yang dapat menyebabkan selama kehamilan banyak terjadi perubahan peningkatan hormon untuk mempertahankan hasil konsepsi sampai terjadinya kelahiran. $^{11}$

Kondisi stres psikologis amygdala akan mengaktifkan jalur stres di hipotalamus dan batang otak yang mengaktifkan noradrenalin dan dopamin, amydala merupakan sistem limbik yang mengatur emosional seseorang. Stres yang ditimbulkan dengan renjatan listrik merupakan stres fisik yang menimbulkan rasa nyeri pada tikus yang dapat meransang reseptor pada kortek frontalis jika stres yang berkelanjutan atau stres yang kronik akan merangsang sekresi kortisol melalui hipotalamus untuk mensekresi $\mathrm{CRH}$ melalui kortek adrenal terjadinya peningkatan sekresi hormon kortisol. ${ }^{12}$

Pendapat lain juga menyatakan bahwa pada saat terjadinya stres ada dua mekanisme tubuh yang akan dipengaruhi yaitu sistem hormonal dan 
neurotransmiter. Pada saat hipotamus menghasilkan dan melepaskan Corticotropic Releasing Hormone $(\mathrm{CRH})$ ke dalam aliran darah, maka $\mathrm{CRH}$ akan menyebabkan hipofisis anterior mengeluarkan hormon adrenokortikotropin (ACTH). Hormon ini beredar dalam darah ke korteks adrenal dan menyebabkan pelepasan hormon kortisol. Stres menyebabkan peningkatan pelepasan $\mathrm{CRH}$ oleh hipotalamus yang kemudian menyebabkan peningkatan ACTH dan kortisol. ${ }^{13}$

Hal ini sesuai dengan penelitian yang dilakukan oleh Shaikh Kiran et al (2013) yang mengatakan peningkatan $\mathrm{CRH}, \mathrm{ACTH}$ dan kortisol akan menyebabkan insufisiensi uteroplasenta dan stres pada janin sehingga oksitosin dan sekresi prostaglandin yang menyebabkan ketuban pecah dini akhirnya terjadi kelahiran premature dan pertumbuhan janin terganggu. ${ }^{14}$

\section{SIMPULAN}

Terdapat penurunan berat badan janin pada induk tikus bunting yang mengalami stres (+) dibandingkan berat badan janin pada induk yang tidak mengalami stres (-). Terdapat penurunan panjang badan janin pada induk yang mengalami stres (+) dibandingkan berat badan janin pada induk yang tidak mengalami stres (-). Terdapat peningkatan kadar kortisol pada induk yang mengalami stres (+) dibandingkan berat badan janin pada induk yang tidak mengalami stres (-).

\section{UCAPAN TERIMA KASIH}

Terima kasih dan penghargaan kepada Kepala Laboratorium Farmakologi Fakultas Farmasi Universitas Andalas dan Kepala Laboratorium Biomedik Fakultas Kedokteran Universitas Andalas beserta staf yang telah memberikan izin penelitian dan membantu dalam menyelesaikan penelitian ini.

\section{DAFTAR PUSTAKA}

1. George M, Maria P, Diamantis KA, George C. Exercise and the stress system. University Medical School. 2005;4(2):73-89.
2. WHO. Improving health system and service for mental health 2009. (diunduh 29 Oktober 2018) Tersedia dari: https:/www.who.int/whosis/whostat/ 2009/en/

3. Kementerian Kesehatan RI (Kemenkes RI). Pusat data dan informasi kementerian kesehatan Republik Indonesia. 2017 (diunduh 29 Oktober 2018). Tersedia dari: http://depkes.go.id/ resources/download/pusdatin/infodatin/infodatinkanker.pdf

4. Amiel T, Cabrol C, Denver D, Jarreu D, Papiernik E.,Piazza $\mathrm{P}$, et al. Adaptation to stress part 1: acceleration of fetal maturation and earlier birth triggered by placental insufficiency in human. Early Human Development. 2004;7(8):15-27.

5. Sherwood, Laurance. Fisiologi manusia: dari sel ke sistem. Edisi ke-6. Yesdelita N, editor penterjemah. Jakarta: EGC; 2011.hlm.356-89.

6. Nurdin AE. Tumbuh kembang prilaku manusia. Edisi ke-5. Jakarta: EGC; 2013.hlm.50-65.

7. Sugito, Erdiansyah R, Muhammad I. Respon HSP70 dan kadar kortisol akibat fraktur kaki tikus (Rattus Norvegicus) bunting. Jurnal Kedokteran Hewan. 2012;6(2):12-6.

8. Guyton CA, Hall JE. Buku ajar fisiologi kedokteran. Edisi ke-12. Setiawan I, editor penterjemah. Jakarta: EGC; 2012.hlm.481-513.

9. Pudjonarko D, Pudjonarko MN, Jenie ED. Nyeri yang diprovokasi electric foot shock, daya bunuh makrofag dan penggunaan imunomodulator bcg pada mencit. Media Medika Indonesian. 2008; 43(3):107-17.

10. Harris A, Seckl R. Glucocorticoids, prenatal stress and the programing of disease. Media Medika Indonesian. 2011;59(3):279-89.

11. Cunningham FG. Obstetri Wiliam.Edisi ke-23. Setia $R$, editor penterjemah. Jakarta: EGC; 2012.hlm.46-82.

12. Arnsten Amy F.T Stress signalling pathway that impair prefrontal cortex structure and functional. Publikasi Medical. 2009;10(6):410-22 .

13. Bregman LR, Trost K. The person-oriented versus the variable-oriented approach: are they complementary, opposites, or exploring different world? Journal of Latin American Studies. 2006; 52(3):601-32. 
14. Shaikh K, Shahirose P, Khurshid K, Suzanne T, Ambreen K. The relationship between prenatal stress, depression, cortisol and preterm birth. A Review Journal Of Depresion. 2013;2(3):24-31. 